\title{
Chemical Forms and Phytoavailability of Copper in Soil as Affected by Crop Residues Incorporation
}

\author{
Shahrzad Kabirinejad ${ }^{1}$, Mahmoud Kalbasi ${ }^{1}$, Amir Hossein Khoshgoftarmanesh ${ }^{2}$, \\ Mehran Hoodaji ${ }^{1}$, Majid Afyuni ${ }^{2}$ \\ ${ }^{1}$ Department of Agriculture, Isfahan (Khorasgan) Branch, Islamic Azad University, Isfahan, Iran \\ ${ }^{2}$ College of Agriculture, Isfahan University of Technology, Isfahan, Iran \\ Email: ${ }^{*}$ kabirinejad@khuisf.ac.ir
}

Received 20 April 2014; revised 2 June 2014; accepted 18 June 2014

Copyright (C) 2014 by authors and Scientific Research Publishing Inc.

This work is licensed under the Creative Commons Attribution International License (CC BY). http://creativecommons.org/licenses/by/4.0/

\section{Open Access}

\section{Abstract}

Preceding crops as a source of organic matter are important sources of micronutrient and can play an important role in the soil fertility and soil cycling of micronutrients. In addition to the role of the organic matter in increasing the concentration of micronutrients in soil solution, attention should be also paid to the role of the kind and the quantity of the root's exudates released in response to the incorporation of different plant residues in the rhizosphere. Present research was conducted with the objective of studying the effect of the kind of preceding crops: Trifolium (Trifolium pretense $L$ ) and Sorghum (Sorghum bicolor $L$ ) on chemical forms of copper (Cu) in solid phases of a calcareous soil in a completely randomized block field experiment with split plot $\mathbf{3} \mathbf{~ m}$ $\times 5 \mathrm{~m}$ ) arrangement, consisting of 3 replications and 3 treatments. After incorporation of the residue, wheat (genotype back cross) was planted. After harvesting the wheat, soil samples were collected from root zone of wheat. Selected soil properties and chemical forms of $\mathrm{Cu}$ were determined in the solid phases of the soil samples. Incorporation of plant residues significantly increased the concentration of DTPA-extractable $\mathrm{Cu}$, in the soil. The highest effect was obtained for Trifolium treatment. Incorporation of plant residues decreased the carbonate-bound $\mathrm{Cu}$ ( $\mathrm{Cu}$ Carb) fraction in the solid phase and increased oxide-bound $\mathrm{Cu}(\mathrm{Cu}-\mathrm{Ox})$ as compared to the control (fallow treatment). Fraction of organic-bound $\mathrm{Cu}(\mathrm{Cu}-\mathrm{Org}$ ) in the soil increased with incorporation of plant residues as compared with the fallow treatment. Trifolium was the most effective in increasing $\mathrm{Cu}-\mathrm{Org}$. $\mathrm{Cu}-\mathrm{Ox}$ and $\mathrm{Cu}$-Residual (Cu-Res) forms showed a significant negative correlation and $\mathrm{Cu}-\mathrm{Org}$ showed a significant positive correlation with the concentration of DTPA-extractable $\mathrm{Cu}$. Incorporation of Trifolium residues decreased the fraction (\%) of $\mathrm{Cu}$-Carb and $\mathrm{Cu}-\mathrm{Ox}$ (less soluble forms) and consequently increased the fraction (\%) of $\mathrm{Cu}$-Org which in turn elevated the concentration of DTPA-extractable Cu. Trifolium was the most effective in increasing the phytoa-

*Corresponding author.

How to cite this paper: Kabirinejad, S., Kalbasi, M., Khoshgoftarmanesh, A.H., Hoodaji, M. and Afyuni, M. (2014) Chemical Forms and Phytoavailability of Copper in Soil as Affected by Crop Residues Incorporation. American Journal of Analytical Chemistry, 5, 604-612. http://dx.doi.org/10.4236/ajac.2014.59068 
vailability of $\mathrm{Cu}$ in soil.

Keywords

Crop Residues, Copper Fractionation, Trifolium, Sorghum, DTPA-Extractable Cu

\section{Introduction}

Copper is a vital micronutrient in organisms, particularly plants, most notably because $\mathrm{Cu}$ participates in protein synthesis, membrane activities, and photosynthesis [1] [2]. The chemical properties of $\mathrm{Cu}$ endow the metal with pivotal roles in cell physiology as a catalytic cofactor in many redox enzymes and as a structural contributor in protein conformation, making $\mathrm{Cu}$ an essential micronutrient for plants or even all organisms. Our knowledge of the mechanisms or processes in plants and soils influencing $\mathrm{Cu}$ oxidation state, speciation, solubility, mobility, uptake and transport in plants, is still scarce in most cases [3]. Copper is often applied to soil and crops as fertilizer to ameliorate micronutrient deficiencies caused by prolonged, intensive agriculture [4]. Therefore, with regard to the key role of $\mathrm{Cu}$ copper in plant, it is necessary that the $\mathrm{Cu}$ chemistry be evaluated in soil. There are several mechanisms for bounding $\mathrm{Cu}$ in soil solid phase such as carbonates, sulfates, $\mathrm{Fe}, \mathrm{Al}$ and $\mathrm{Mn}$ oxides and organic matter. On the other hand, the distribution of $\mathrm{Cu}$ in different chemical forms influences its bioavailability. Cu Copper has also a strong tendency to bind to organic compounds, which in turn can affect its availability for plant uptake. Agbnyn (2010) showed that the characteristic chemical and physical soil organic matter played an important role in formation of $\mathrm{Cu}$ forms in the soil [5]. Incorporation of crop residues into the soil as a source of organic matter and micronutrients such as $\mathrm{Cu}$ can play an important role in the soil fertility and cycling of micronutrients. Because organic acids released from decomposition of crop residues can alter the mobility and bioavailability of metals such as $\mathrm{Cu}$ in the soil by modifying soil $\mathrm{pH}$ or by releasing soluble organic compounds to complex $\mathrm{Cu}$. For example, about $50 \%$ to $80 \%$ of $\mathrm{Zn}$, Cu and $\mathrm{Mn}$ taken up by rice and wheat crops can be recycled through residue incorporation [6]. Sequential fractionation can be used to determine the amounts and chemical forms of trace elements, as well as to infer the potential bioavailability and to predict the mobility affecting their movement within the soil profile and into groundwater. The number of studies concerning the effect of crop residues incorporation on the fractions of $\mathrm{Cu}$ in the soil solid phase and bioavailablility of $\mathrm{Cu}$ for plant are limited. Therefore, the objectives of this study were to investigate the effects of crop residues on: 1) the fractions of $\mathrm{Cu}$ in the soil solid-phase. 2) on the Cu bioavailability (DTPA-extractable $\mathrm{Cu}$ ) in soil.

\section{Methods and Materials}

\subsection{Field Experiment}

The field selected for experiment was located in an area in the southeast city of Esfahan, in the central part of Iran. This area has a relatively flat topography with medium to heavy textured soils. The climate condition is dry with low annual rainfall $(<100 \mathrm{~mm})$ and high evapotranspiration $(>1500 \mathrm{~mm})$. The soil in the experimental site was classified as Typic Haplocalcids (Soil Classification Working Group, 1998).

Treatments consisted of control (fallow) plus incorporation of the residues of 2 crops: Trifolium (Trifolium pretense L.) and Sorghum (Sorghum bicolor L.) and subsequent planting of wheat (Back Cross genotype) in 3 replications. The experiment was conducted in a complete randomized block field experiment. This made a total of 9 plots $(5 \times 3)$. The air-dried crop residues were crashed into the $0.5-2 \mathrm{~cm}$ pieces and were completely incorporated into the top soil $(0-30 \mathrm{~cm})$ of each plot with $7 \mathrm{Mg} /$ ha rate. Wheat was planted 30 days after crop residues incorporation and was harvested the following spring. Crop and soil samples were collected at the time of harvest. Soil samples were air-dried, ground and passed through $2 \mathrm{~mm}$ sieve and stored for chemical analysis. Available $\mathrm{Cu}$ in the soil samples was extracted by diethylenetetramine-penta-aceticacid (DTPA) and Cu concentration in the extract was determined using atomic absorption spectroscopy [7]. Selected properties of the top soil used in this study are shown in Table 1.

\subsection{Sequential Extraction of Soil}

Fractionation of soil Cu was carried out using the MSEP method [8]. All the five operationally defined binding 
fractions (exchangeable, bound to carbonates, bound to Mn-oxides and Fe-oxides, bound to OM and residual) could then be extracted using this method. The details of the MSEP are described in Table 2.

During the extractions, a centrifugation was performed at 3000 RPM to separate extracts from solid. The supernatants were transferred into $50 \mathrm{ml}$ volumetric flask and diluted with $\mathrm{DI}-\mathrm{H}_{2} \mathrm{O}$, then analyzed with flame atomic absorption spectrometer (AAS) for $\mathrm{Cu}$.

\subsection{Data Analyses}

All statistical analyses were carried out using SAS program. Comparison of the mean values of treatments were tested using one-way analysis of variance (ANOVA). Significant differences between pairs of mean were identified using the LSD test at 5\% level [9].

\section{Results and Discussion}

\subsection{Properties of Plant Residues}

Table 3 shows $\mathrm{C} / \mathrm{N}$ ratio and $\mathrm{Cu}$ concentration of crop residues. The highest and lowest carbon to nitrogen ratios were related to Sorghum and Trifolium residues, respectively. The highest concentration of Cu was observed for Trifolium residues. Lower $\mathrm{C} / \mathrm{N}$ ratio of Trifolium caused rapid decomposition of organic compounds and subsequent production of organic acids resulting in lower $\mathrm{pH}$ (Table 3).

\subsection{Effect of Plant Residues Incorporation on Soil DTPA Extractable Cu}

All the treatments significantly increased the concentration of DTPA-extractable $\mathrm{Cu}$ in soil. The highest effect was obtained for Trifolium and then Sorghum treatment (Figure 1).

Incorporation of crop residues decreased soil $\mathrm{pH}$ that could increase the solubility and availability of $\mathrm{Cu}$ compound. It also increased organic matter content and consequently increased the amount of $\mathrm{Cu}$ complexed with organic ligands. In addition, residues contains $\mathrm{Cu}$ which could be released upon decomposition of plant residues in soil. Stevenson (1991) reported that application of organic fertilizers increased the concentration and

Table 1. Selected soil properties.

\begin{tabular}{|c|c|c|c|c|c|c|c|c|c|c|c|c|}
\hline Classification & Clay & Silt & Sand & $\mathrm{pH}$ & $\begin{array}{c}\mathrm{EC} \\
(\mathrm{dS} / \mathrm{m})\end{array}$ & $\begin{array}{l}\mathrm{OM} \\
(\%)\end{array}$ & $\begin{array}{c}\mathrm{CaCO}_{3} \\
(\%)\end{array}$ & $\begin{array}{c}\mathrm{N} \\
(\%)\end{array}$ & $\begin{array}{l}\text { Olsen-P } \\
\text { (mg/kg) }\end{array}$ & $\begin{array}{c}\mathrm{NH}_{4}-\mathrm{OACK} \\
(\mathrm{mg} / \mathrm{kg})\end{array}$ & $\begin{array}{c}\text { Cu DTPA } \\
\text { (mg/kg) }\end{array}$ & $\begin{array}{c}\text { Cu Total } \\
(\mathrm{mg} / \mathrm{kg})\end{array}$ \\
\hline Typic haplocalcids & 42.5 & 46.3 & 21.2 & 7.5 & 6 & 0.4 & 33 & 0.05 & 11 & 289 & 1.4 & 35.8 \\
\hline
\end{tabular}

Table 2. Summary of the Tessier et al. (1979) sequential extraction procedure.

\begin{tabular}{|c|c|c|c|}
\hline Step & Fractions & Reagent & Shaking time and temperature \\
\hline 1 & Exchangeable (EXC) & $8 \mathrm{ml}$ of $1 \mathrm{M} \mathrm{MgCl}_{2}(\mathrm{pH} 7)$ in $1 \mathrm{~g}$ soil & $2 \mathrm{~h}$ at $25^{\circ} \mathrm{C}$ \\
\hline 2 & Bound to carbonates (CAR) & $8 \mathrm{ml}$ of $\mathrm{NaOAc}$ (pH 5.0 with HOAc) & $5 \mathrm{~h}$ at $25^{\circ} \mathrm{C}$ \\
\hline 3 & $\begin{array}{l}\text { Amorphous iron-manganese } \\
\text { oxides (OXI) }\end{array}$ & $\begin{array}{l}20 \mathrm{ml} \text { of } 0.04 \mathrm{M} \text { hydroxylamine hydrochloride in } \\
\left.25 \% \text { acetic acid (pH } 2 \text { with } \mathrm{HNO}_{3}\right)\end{array}$ & $6 \mathrm{~h}$ at $96^{\circ} \mathrm{C}$ \\
\hline 4 & Organic-bound (ORG) & $\begin{array}{l}5 \mathrm{ml} \text { of } 30 \% \mathrm{H}_{2} \mathrm{O}_{2}(\mathrm{pH} 2) \text {, plus } 3 \mathrm{ml} \text { of } 0.02 \mathrm{M} \mathrm{HNO}_{3} \text { and } \\
3 \mathrm{ml} \text { of } 30 \% \mathrm{H}_{2} \mathrm{O}_{2}(\mathrm{pH} \text { 2) Cool, add } 20 \mathrm{ml} \text { of a mixture } \\
\text { of } 3.2 \mathrm{M} \mathrm{NH}_{4} \mathrm{Ac} \text { and } 20 \% \mathrm{HNO}_{3}\end{array}$ & $2 \mathrm{~h}$ at $85^{\circ} \mathrm{C}$ \\
\hline 5 & Residual (RES) & $\begin{array}{l}\text { The residual fraction was digested by } 8 \mathrm{ml} \text { of a mixture } \\
\text { of } \mathrm{HCl} \text { and } \mathrm{HNO}_{3} \text { Volume ratio of } 3 \text { to } 1 \text {, therefore they } \\
\text { were reached by } 0.5 \mathrm{M} \mathrm{HNO}_{3}\end{array}$ & $30 \mathrm{~min}$ at $25^{\circ} \mathrm{C}$ \\
\hline
\end{tabular}

Table 3. $\mathrm{C} / \mathrm{N}$ ratio and $\mathrm{Cu}$ concentration of crop residues.

\begin{tabular}{cccc} 
Plant residues & C/N & Concentration of Cu $(\mathrm{mg} / \mathrm{kg})$ & Soil pH \\
Sorghum bicolor $L$. & 54.2 & 4.9 & 7.3 \\
Trifolium pretense L. & 19.2 & 8.2 \\
\hline
\end{tabular}


availability of micronutrients in the soil [10]. Eghball et al., (2004) observed that application of organic fertilizers increased the availability of zinc for corn [11].

\subsection{Effect of Plant Residues on Cu Fractions in Soil}

\subsubsection{Exchangeable $\mathrm{Cu}$}

Amount of exchangeable $\mathrm{Cu}$ in the soil samples was lower than AAS detection limit, therefore could not be measured with sufficient accuracy. Payne et al., (1988) showed that the exchangeable $\mathrm{Cu}$ is available for plant. Exchangeable form of $\mathrm{Cu}$ is usually the lowest form of $\mathrm{Cu}$ in soil [12]. Gankl et al., (2002) and (2003) and $\mathrm{Yu}$ and Zhou (2006) have also pointed out this [13]-[15].

\subsubsection{Carbonate-Bound $\mathrm{Cu}$ (Cu-Carb)}

Crop residues treatments significantly decreased $(p<0.05)$ Cu-Carb in soil in comparison with the control (Table 4). Largest amount of Cu-Carb was found in Sorghum treated plots while Trifolium treated plots had the lowest amount of $\mathrm{Cu}$-Carb (Figure 2). Concentration of $\mathrm{Cu}$-Carb in the Trifolium treated plots significantly decreased $12 \%$ in comparison with the control. In this study, Cu-Carb ranged from $0.87 \mathrm{mg} / \mathrm{kg}$ in Trifolium treated plots to1.4 mg/kg in the control plot. Ma and Uren (1995) reported that in calcareous soils, the average Cu-Carb is from $0.5-1.25 \mathrm{mg} / \mathrm{kg}$ of soil [16]. Ramos et al., (1994) reported that average of Cu carb is about $0.92 \mathrm{mg}$ per $\mathrm{kg}$ of soil [17]. Reduction of Cu-Carb concentration in soil as the results of crop residue incorporation probably was due to their impact on reducing soil $\mathrm{pH}$, which in turn might have increased the solubility of carbonate compounds in soil. Trifolium-treated plots was more effective than Sorghum-treated plots in reducing soil pH that could be the reason for the higher effect in reducing the concentration of Cu-carb (Table 3). Mehra and Jackson (1960) reported that $\mathrm{Cu}$ in calcareous soils appeared to precipitate as carbonate or hydroxides [18]. Wei et al., (2006) reported that available $\mathrm{Cu}$ was negatively correlated with soil available $\mathrm{P}$ and $\mathrm{CaCO}_{3}$ content and a positively correlated with $\mathrm{pH}$. In this study, Cu-Carb was from $0.87 \mathrm{mg} / \mathrm{kg}$ in Trifolium treatment and $1.4 \mathrm{mg} / \mathrm{kg}$ in control [19].

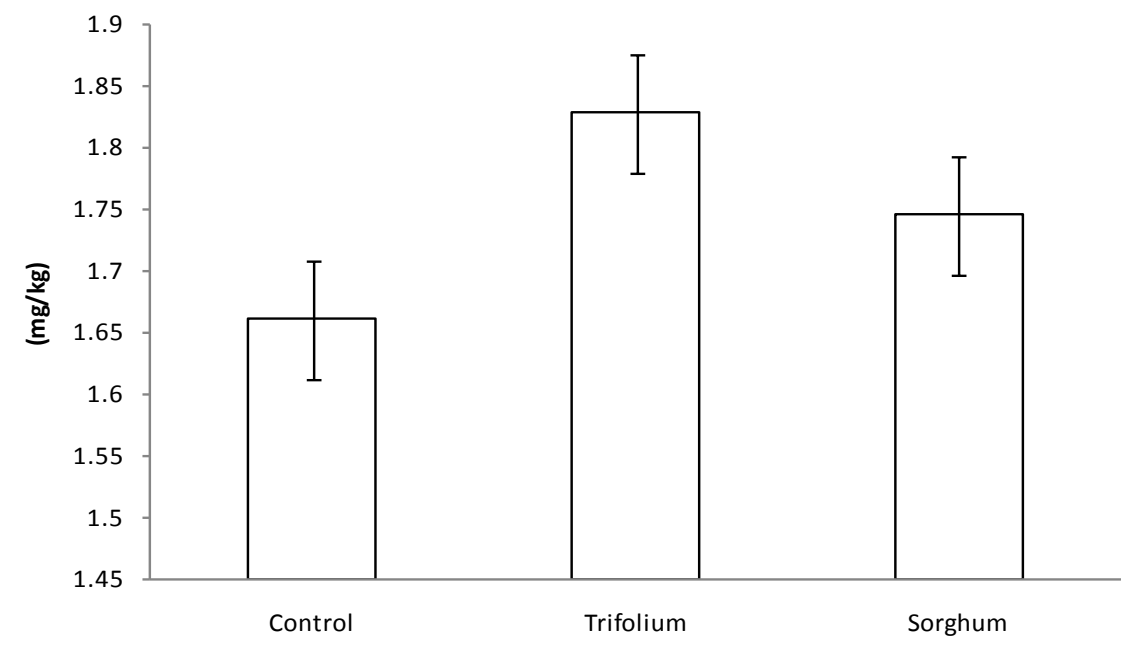

Figure 1. The effect of crop residues on the concentration of DTPA-extractable $\mathrm{Cu}$.

Table 4. Analysis of variance of different fractions of $\mathrm{Cu}\left(\mathrm{mg} \cdot \mathrm{kg}^{-1}\right)$ in soil as affected by Incorporation of crop residues treatments.

\begin{tabular}{cccccc}
\hline & \multicolumn{5}{c}{ Mean Square } \\
\hline Source of Variation & df & Cu-Carbonate & Cu-Oxide & Cu-Organic & Cu-Residual \\
\hline Replication (RE) & 2 & 0.018 & 0.12 & 0.019 & 3 \\
Crop residues (P) & 2 & $0.12^{*}$ & $1.17^{* * *}$ & $5.72^{* * *}$ & 3.77 \\
Error & 6 & 0.53 & 0.039 & 1.094 & 1.81 \\
\hline
\end{tabular}

*** ${ }^{* *}$, ${ }^{*}$ Sighnificant at $0.001,0.01$ and 0.05 levels, respectively. 


\subsubsection{Fe and Mn-Oxides}

Sorghum treatment significantly increased $(p<0.001)$ the concentration of soil $\mathrm{Cu}-\mathrm{Ox}$ in comparison with the control treatment. Trifolium treatment, on the other hand, significantly decreased the concentration of soil $\mathrm{Cu}-\mathrm{Ox}$ as compared with the control (Figure 3). Indeed the concentration of soil Cu-Oxide by Trifolium treatment decreased $14 \%$, also increased $5.3 \%$ by Sorghum treatment in comparison with the control. Reduction of the concentration of soil Cu-Ox by Trifolium treatment may have been due to its effect on increasing the concentration of $\mathrm{Cu}$-Org in soil. Indeed, when $\mathrm{Cu}$ is added to the soil, a series of interactions (e.g., adsorption, precipitation, complexation, etc.) would take place. The metal forms, associated with $\mathrm{Fe}, \mathrm{Al}$ and $\mathrm{Mn}$ oxides, or bound with organic matter, could be considered potentially active or strongly bound, depending on the physical properties of soil [20]-[25]. Therefore, the form of $\mathrm{Cu}-\mathrm{Ox}$ can act as a buffering capacity and potential for $\mathrm{Cu}$ in soil.

\subsubsection{Organically Bound Cu (Cu-Org)}

Concentration of $\mathrm{Cu}$-Org significantly $(p<0.001)$ increased with the crop residues incorporation as compared with the control (Table 4). The largest amount of $\mathrm{Cu}$-Org was found for the Trifolium treated plots (Figure 4). Indeed in the Trifolium and Sorghum treated plots Cu-Org significantly increased $72 \%$ and $50 \%$, respectively in comparison with the control.

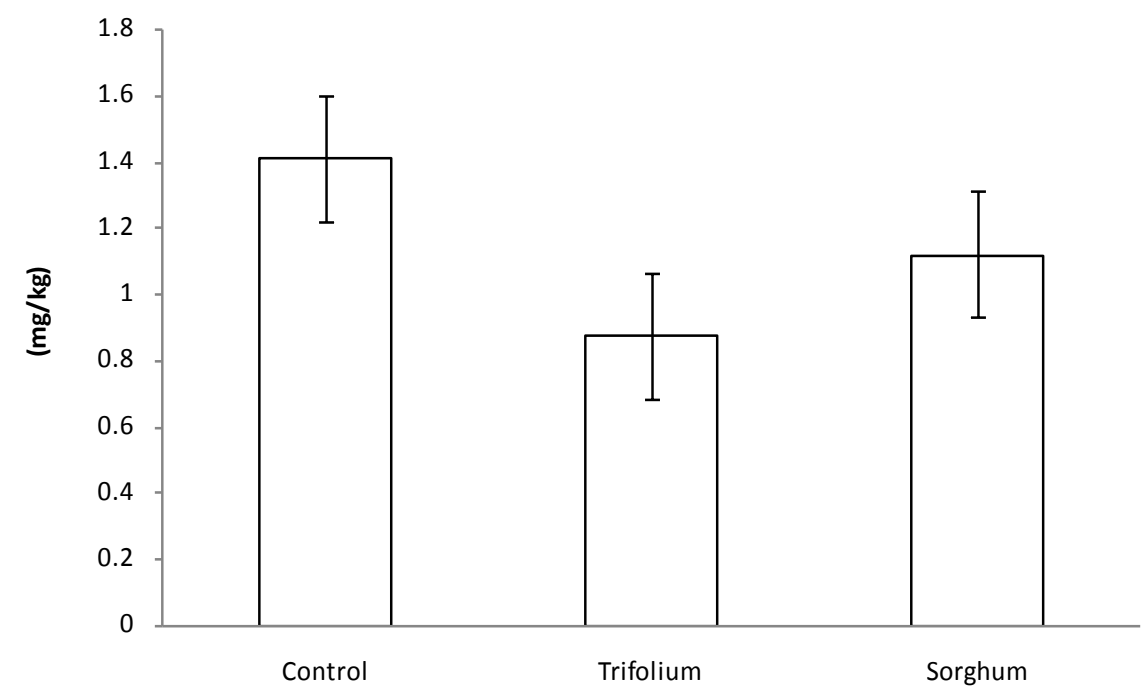

Figure 2. The effect of crop residues on Cu-Carbonate.

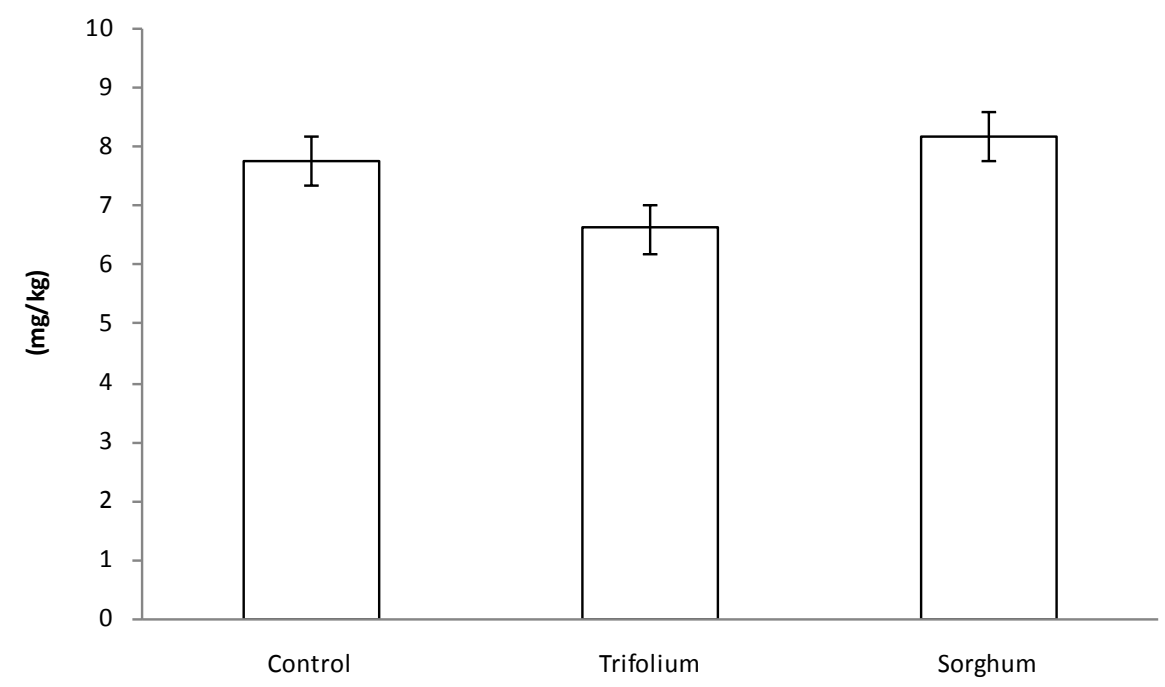

Figure 3. The effect of crop residues on Cu-Oxide. 


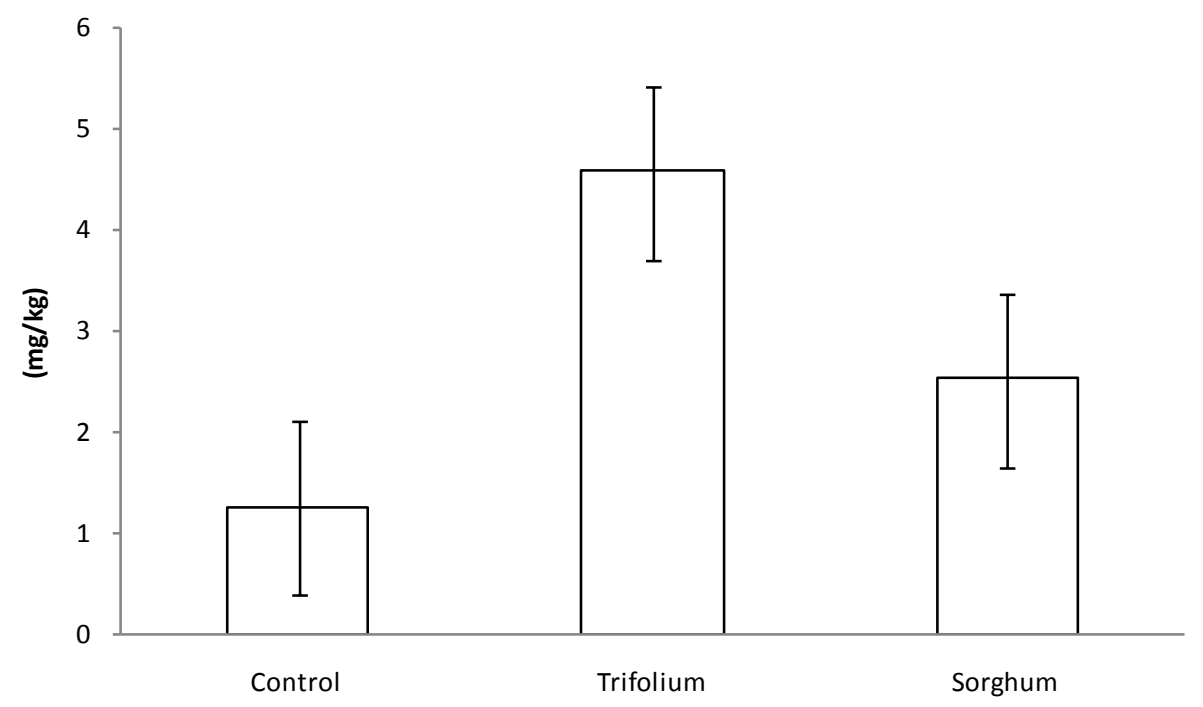

Figure 4. The effect of crop residues on Cu-Organic.

Higher increase of $\mathrm{Cu}$-Org in Trifolium-treated plots was probably due to the lower $\mathrm{C} / \mathrm{N}$ ratio of trifolium and consequent increase in decomposition of the added residues resulting in higher soluble organic matter and higher complexation of $\mathrm{Cu}$ by organic matter. Krishnamurti and Naidu (2002) showed that the partition coefficient of soil $\mathrm{Cu}$ was strongly influenced by the fraction complexed with soil organic matter [26].

Kawasaki et al. (2000) reported that most of the $\mathrm{Cu}$ in industrial effluents, are in organic form [27]. McGrath et al., (1998) demonstrated that increase in soil organic matter resulted in the transfer of copper from other forms to organic form [28].

Part of this $\mathrm{Cu}$ (Cu bound to fulvic acids) can move to soil solution and exist as a part of dissolved $\mathrm{Cu}$ which is assumed to be an important factor in the phytoavailability of soil $\mathrm{Cu}$. Tao et al., (2003) in reported that the results of the five-step sequential extraction process followed the order: Organic (47.4\%), Residual (30.8\%), Oxide (15.9\%), Carbonate (5.4\%), and Exchangeable (0.5\%) [29]. Other authors have already stated that the $\mathrm{Cu}-\mathrm{Org}$ is the dominant fraction (mean $40.7 \%$ ) in soils [30].

\subsubsection{Residual Cu Form (Cu-Res)}

Incorporation of Trifolium residues decreased Cu-Res in comparison with the control (Table 4) although the decrease was not significant (Figure 5). In this study around $90 \%$ and $66 \%$ of $\mathrm{Cu}$ fractions were in the form of $\mathrm{Cu}$-Res in control and in Trifolium treatment, respectively.

Copper has a stronger affinity to associate with the crystalline structures of the minerals and the organic ligands. As Fuentes et al., (2004) and Nemati et al., (2009) have also pointed out [31] [32]. Burt et al. (2003) reported that around $93 \%$ of $\mathrm{Cu}$ and $41 \%$ of $\mathrm{Zn}$ was recovered as residual fraction and very low percentage of $\mathrm{Cu}$ was recovered as water soluble and exchangeable fractions [33]. Schramel et al. (2000) found that the copper bound in the residual phase in an uncontaminated soil was around 65\% - 85\% [34]. Review effect Trifolium on other forms of copper in soil identified that likely the effect of Trifolium on Cu-Organic with compared to Sorghum cause that decreased Cu-residual.

Overall distribution of $\mathrm{Cu}$ among different fractions followed the order below:

$$
\mathrm{Cu}-\mathrm{Res}>\mathrm{Cu}-\mathrm{Ox}>\mathrm{Cu}-\mathrm{Org}>\mathrm{Cu}-\mathrm{Carb}
$$

\subsection{Relationships between Forms of $\mathrm{Cu}$ in Soil Solid Phase with DTPA-Extractable Cu}

$\mathrm{Cu}$-Carb showed no significant correlation with DTPA-extractable $\mathrm{Cu}$ in soil. $\mathrm{Cu}-\mathrm{Ox}$ and $\mathrm{Cu}-\mathrm{Res}$ forms showed a significantly negative correlation (0.05 and 0.01), respectively with DTPA-extractable Cu (Table 5). Amount of bioavailable $\mathrm{Cu}$ reduced by carbonates and oxides [35]. Cu-Org form showed a significant positive correlation (0.01) with DTPA-extractable $\mathrm{Cu}$. This suggests that crop residues incorporation resulted in an increase in soil organic matter and consequent increase in the amount of $\mathrm{Cu}$ complexed with organic matter and bioavailable in 


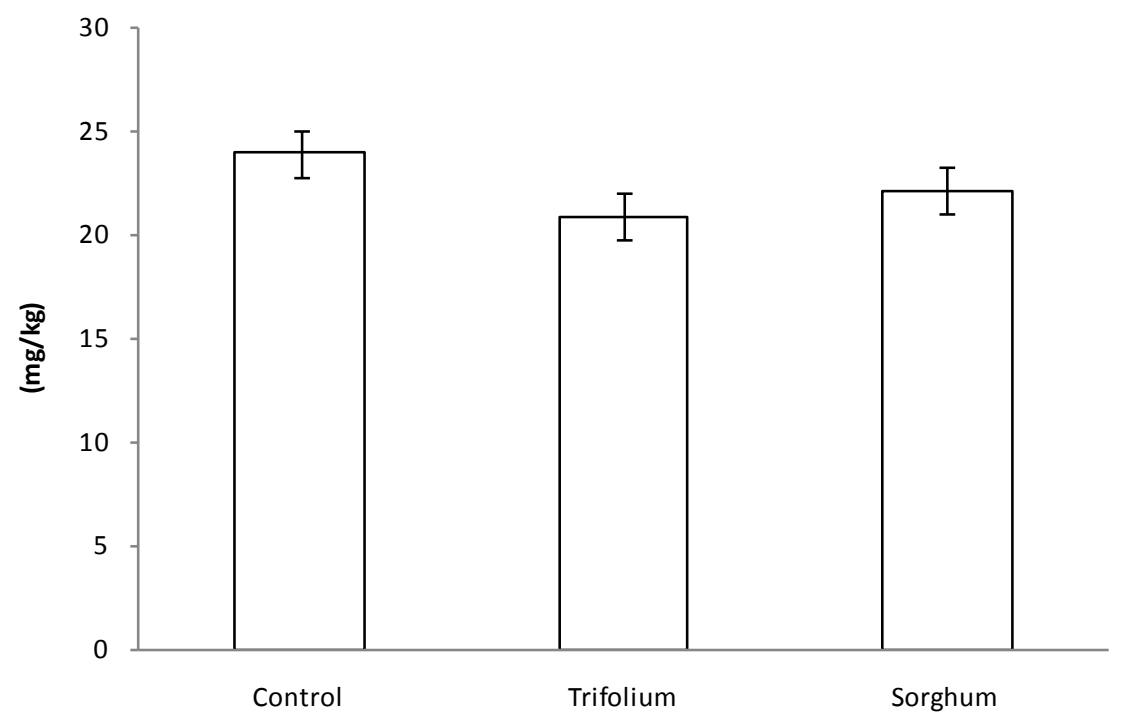

Figure 5. The effect of crop residues on Cu-Residual.

Table 5. Regression coefficient $\left(\mathrm{r}^{2}\right)$ between $\mathrm{Cu}$ fractions and the concentration of DTPA-extractable Cu in soil.

\begin{tabular}{cccc}
\hline Cu-Carbonate & Cu-Oxide & Cu-Organic & Cu-Residual \\
\hline $0.56^{\text {ns }}$ & $0.63^{*}$ & $0.78^{* *}$ & $0.72^{* *}$ \\
\hline
\end{tabular}

${ }^{* *}$ Significant at $p<0.01$; ${ }^{*}$ Significant at $p<0.05$; ${ }^{\text {ns }}$ Non significant.

soil. Gunkel et al., (2003) reported that organic forms of $\mathrm{Cu}$ are most correlated with available forms of $\mathrm{Cu}$ for plant uptake.

\section{References}

[1] Frausto da Silva, J.J.R. and Williams, R.J.P. (2001) The Biological Chemistry of the Elements. The Inorganic Chemistry of Life, University Press, Oxford, 584 p.

[2] Koch, K.A., Pena, M.M.O. and Thiele, D.J. (1997) Copper-Binding Motifs in Catalysis, Transport, Detoxification and Signaling. Chemistry \& Biology, 4, 549-560. http://dx.doi.org/10.1016/S1074-5521(97)90241-6

[3] Yruela, I. (2005) Copper in Plants. Brazilian Journal of Plant Physiology, 17, 145-156. http://dx.doi.org/10.1590/S1677-04202005000100012

[4] Karamanos, K., Peratzakis, A., Kapiris, P., Nikolopoulos, S., Kopanas, J. and Eftaxias, K. (2005) Extracting Preseismic Electromagnetic Signatures in Terms of Symbolic Dynamics. Nonlinear Processes in Geophysics, 12, 835-848. http://dx.doi.org/10.5194/ngg-12-835-2005

[5] Agbenin, J.O. (2010) Extractability and Transformation of Copper and Zinc Added to Tropical Savanna Soil under Long-Term Pasture. Communications in Soil Science and Plant Analysis, 41, 1016-1027. http://dx.doi.org/10.1080/00103621003648150

[6] Prasad, B. and Sinha, S.K. (1995) Nutrient Recycling through Crop Residues Management for Sustainable Rice and Wheat Production in Calcareous Soil. Fertility News, 40, 15-23.

[7] Pyddtt, F.B. (1999) Comparison of Foliar and Stem Bioaccumulation of Heavy Metals by Corsican Pines in the Mount Olympus Area of Cyprus. Ecotoxicology and Environmental Safety, 42, 57-61. http://dx.doi.org/10.1006/eesa.1998.1726

[8] Tessier, A., Campbell, P.G.C. and Bisson, M. (1979) Sequential Extraction Procedure for the Speciation of Particulate Trace Metals. Analytical Chemistry, 51, 844-851. http://dx.doi.org/10.1021/ac50043a017

[9] SAS Institute (1999) SAS System for Windows. Release 8.02. SAS Institute, Cary.

[10] Stevenson (1994) Human Chemistry: Genesis, Composition Reactions. John Wiley and Sons, New York.

[11] Eghball, B., Ginting, D. and Gilley, J.E. (2004) Residual Effects of Manure and Compost Applications on Corn Production and Soil Properties. Agronomy Journal, 96, 442-447. http://dx.doi.org/10.2134/agronj2004.0442 
[12] Payne, G.G., Martens, D.C., Kornegay, E.T. and Lindemann, M.D. (1988) Availability and Form of Copper in Three Soils Eight Annual Application of Copper-Enriched Swine Manure. Journal of Environmental Quality, 17, 740-746. http://dx.doi.org/10.2134/jeq1988.00472425001700040038x

[13] Gunkel, P., Jezequel, K. and Faber, B. (2002) Temporal Evolution of Copper Distribution in Soil Fractions, Influence of Soil pH and Organic Carbon Level on Copper Distribution. Environmental Technology, 23, 1001-1008.

[14] Gunkel, P., Roth, E. and Faber, B. (2003) Copper Distribution in Chemical Soil Fractions and Relationships with Maize Crop Yield. Environmental Chemistry Letters, 1, 92-97. http://dx.doi.org/10.1007/s10311-002-0003-6

[15] Yu, Y. and Zhou, Q.X. (2006) Impacts of Soybean Growth on Cu Speciation and Distribution in Two Rhizospher Soils. Biology and Fertility of Soils, 42, 450-456.

[16] Ma, Y.B. and Uren, N.C. (1995) Application of a New Fractionation Scheme for Heavy Metals in Soils. Communications in Soil Science and Plant Analysis, 26, 3291-3303. http://dx.doi.org/10.1080/00103629509369527

[17] Ramos, L., Hernandez, L. and Gonzalez, M.J. (1994) Sequential Fractionation of Copper, Lead, Cadmium and Zinc in Soils from or Near Donana Natioinal Park. Journal of Environmental Quality, 23, 50-57. http://dx.doi.org/10.2134/jeq1994.00472425002300010009x

[18] Mehra, O.P. and Jackson, M.L. (1960) Iron Oxide Removal from Soils and Clays by a Dithionate-Citrate System Buffered with Sodium Carbonate. Proceedings of the National Conference on Clays and Clay Minerals, Pergamon Press, New York, 317-327.

[19] Wei, X.R., Hao, M.D., Shao, M.G. and Gale, W.J. (2006) Changes in Soil Properties and Availability of Soil Micronutrients after 18 Years of Cropping and Fertilization. Soil and Tillage Research, 91, 120-130. http://dx.doi.org/10.1016/j.still.2005.11.009

[20] Ahumada, I., Escudero, P., Castillo, G., Carrasco, A., Ascar, L. and Fuentes, E. (2004) Use of Sequential Extraction to Assess the Influence of Sewage Sludge Amendment on Metal Mobility in Chilean Soils. Journal of Environmental Monitoring, 6, 327-334.

[21] Arain, M.B., Kazi, T.G., Jamali, M.K., Jalbani, N., Afridi, H.I. and Shah, A. (2008) Total Dissolved and Bioavailable Elements in Water and Sediment Samples and Their Accumulation in Oreochromis mossambicus of Polluted Manchar Lake. Chemosphere, 70, 1845-1856. http://dx.doi.org/10.1016/j.chemosphere.2007.08.005

[22] Jamali, M.K., Kazi, T.G., Arain, M.B., Afridi, H.I., Jalbani, N. and Adil, R.S. (2006) Correlation of Total and Extractable Heavy Metals from Soil and Domestic Sewage Sludge and Their Transfer to Maize (Zea mays L.) Plants. Toxicological \& Environmental Chemistry, 88, 619-632. http://dx.doi.org/10.1080/02772240600875052

[23] Jamali, M.K., Kazi, T.G., Arain, M.B., Afridi, H.I., Jalbani, N. and Memon, A.R. (2007) Heavy Metal Contents of Vegetables Grown in Soil, Irrigated with Mixtures of Wastewater and Sewage Sludge in Pakistan, Using UltrasonicAssisted Pseudo-Digestion. Journal of Agronomy and Crop Science, 193, 218-228. http://dx.doi.org/10.1111/j.1439-037X.2007.00261.x

[24] Jamali, M.K., Kazi, T.G., Arain, M.B., Afridi, H.I., Jalbani, N., Memon, A.R. and Shah, A. (2007) Heavy Metal from Soil and Domestic Sewage Sludge and Their Transfer to Sorghum Plants. Environmental Chemistry Letters, 5, 209-218. http://dx.doi.org/10.1007/s10311-007-0101-6

[25] Kabala, C. and Singh, B. (2001) Fractionation and Mobility of Copper, Lead and Zinc in Soil Profiles in the Vicinity of a Copper Smelter. Journal of Environmental Quality, 30, 485-492. http://dx.doi.org/10.2134/jeq2001.302485x

[26] Krishnamurti, G.S.R. and Naidu, R. (2002) Solid-Solution Speciation and Phytoavailability of Copper and Zinc in Soil. Environmental Science \& Technology, 36, 2645-2651. http://dx.doi.org/10.1021/es001601t

[27] Kawasaki, A., Kimura, R. and Arai, S. (2000) Fractionation of Trace Elements in Wastewater Treatment Sludges. Communications in Soil Science and Plant Analysis, 31, 2413-2423. http://dx.doi.org/10.1080/00103620009370595

[28] McGrath, S., Sanders, J.R. and Shalaby, M.H. (1998) The Effect of Soil Organic Matter Levels on Soil Solution Concentrations and Extractabilities of Manganese, Zinc and Cooper. Geoderma, 42, 177-188. http://dx.doi.org/10.1016/0016-7061(88)90033-X

[29] Tao, S., Chen, Y.J., Xu, F.L., Cao, J. and Li, B.G. (2003) Changes of Copper Speciation in Maize Rhizosphere Soil. Environmental Pollution, 122, 447-454. http://dx.doi.org/10.1016/S0269-7491(02)00313-5

[30] Arias, M., López, E., Fernández, D. and Soto, B. (2004) Copper Distribution and Dynamics in Acid Vineyard Soils Treated with Copper-Based Fungicides. Soil Science, 169, 796-805. http://dx.doi.org/10.1097/01.ss.0000148739.82992.59

[31] Fuentes, A., Llorens, M., Saez, J., Soler, A., Aguilar, M.I., Ortuno, J.F. and Meseguer, V.F. (2004) Simple and Sequential Extractions of Heavy Metals from Different Sewage Sludges. Chemosphere, 54, 1039-1047. http://dx.doi.org/10.1016/j.chemosphere.2003.10.029

[32] Nemati, K., Abu Bakar, N.K., Sobhanzadeh, E. and Abas, M.R. (2009) A Modification of the BCR Sequential Extraction Procedure to Investigate the Potential Mobility of Copper and Zinc in Shrimp Aquaculture Sludge. Microchemical 
Journal, 92, 165-169. http://dx.doi.org/10.1016/j.microc.2009.03.002

[33] Burt, R., Wilson, M.A., Keck, T.J., Dougherty, B.D., Strom, D.E. and Lindahl, J.A. (2003) Trace Element Speciation in Selected Smelter-Contaminated Soils in Anaconda and Deer Lodge Valley, Montana, USA. Advances in Environmental Research, 8, 51-67. http://dx.doi.org/10.1016/S1093-0191(02)00140-5

[34] Schramel, O., Michalke, B. and Kettrup, A. (2000) Study of the Copper Distribution in Contaminated Soils of Hop Fields by Single and Sequential Extraction Procedures. Science of the Total Environment, 263, 11-22. http://dx.doi.org/10.1016/S0048-9697(00)00606-9

[35] Lindsay, W.L. (1991) Iron Oxide Solubilization by Organic Matter and Its Effect on Iron Availability. Plant and Soil, 130, 27-34. http://dx.doi.org/10.1007/BF00011852 
Scientific Research Publishing (SCIRP) is one of the largest Open Access journal publishers. It is currently publishing more than 200 open access, online, peer-reviewed journals covering a wide range of academic disciplines. SCIRP serves the worldwide academic communities and contributes to the progress and application of science with its publication.

Other selected journals from SCIRP are listed as below. Submit your manuscript to us via either submit@scirp.org or Online Submission Portal.
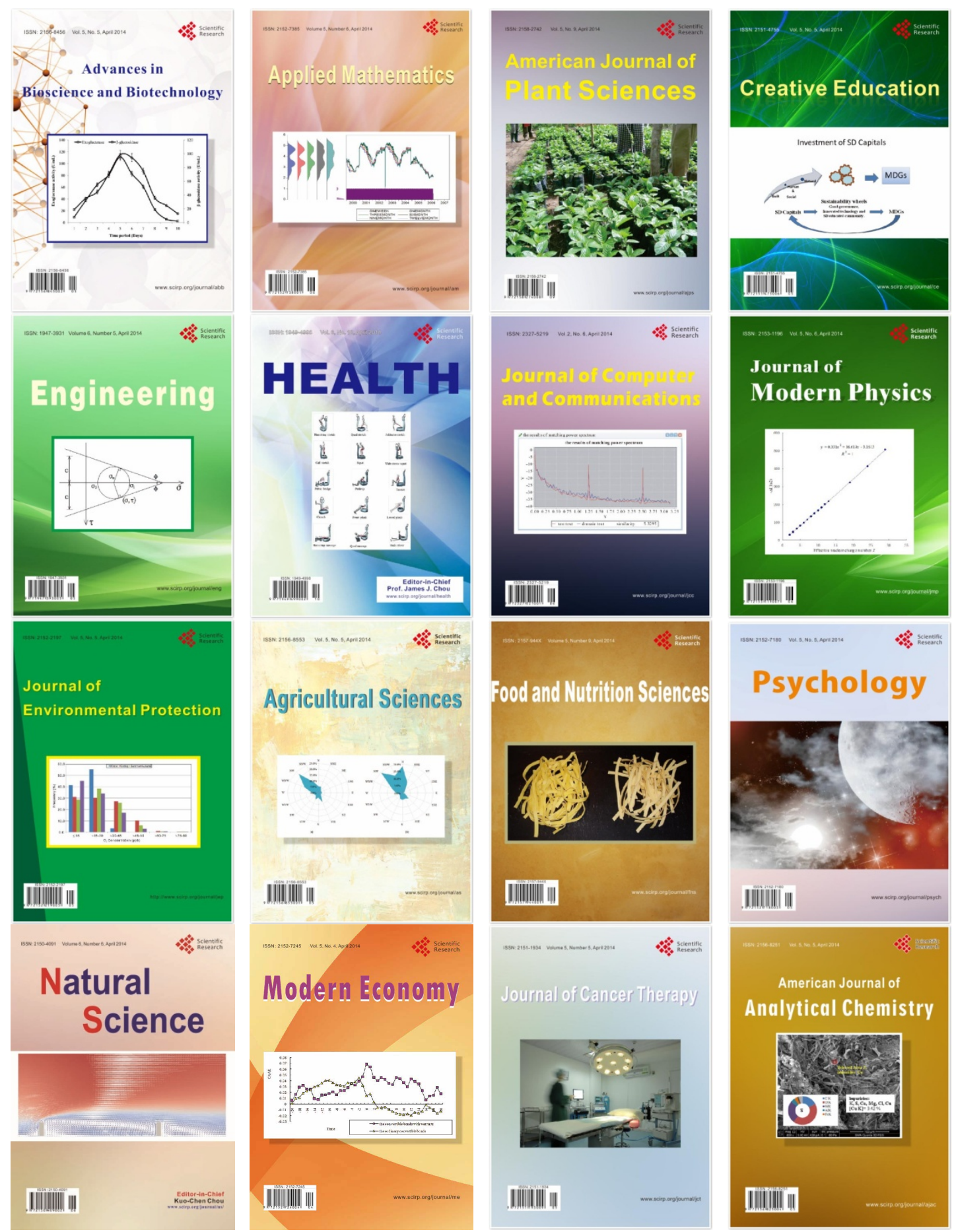